\title{
10
}

\section{Inter organisational systems as a backbone for organisational DSS: scope, impact, examples}

\section{Loebbecke}

University of Cologne

Wilh.-Backhaus-Str. 23, 50931 Koeln, Germany

Tel./ fax: +49-221-444 900

e-mail claudia.loebbecke@uni-koeln.de

P. Powell

Information Systems Research Unit

Warwick Business School

University of Warwick

Coventry, CV4 7AL, UK

Tel: +44-1203-524658

e-mail orspp@razor.wbs.warwick.ac.uk

P. Finnegan

Executive Systems Research Centre

University College Cork

Ireland

Tel: +35321276871

e-mail lect2.ersc.ucc.ie

and

W. Golden

University College Galway

Ireland

Tel: +3539175030

e-mail willie.golden@ugc.ie 


\begin{abstract}
Organisations have had links with others and have operated globally for decades. However, these links were largely at arm's length, though now information systems linking organisations are emerging. Recent technological developments in communications and networking and management moves such as outsourcing, partnerships and just-in-time production have given a new capability and impetus to these issues. This chapter discusses inter-organisational systems (IOS) and identifies why managers need to consider them differently from other, internal, information systems. It looks at different types of IOS along the dimensions of functional scope and IOS-autonomy, IOS-induced business transformation, and issues of IOS planning and design. Further, the chapter outlines new business opportunities afforded by combining the mutually interdependent strategy of cooperation and IOS which span corporate boundaries.
\end{abstract}

\title{
Keywords
}

Inter organisational systems, flexibility, management implications, business scope

\section{INTRODUCTION}

IT will play a major role in the development and operation of inter-organisational co-operation (Venkatraman, 1991). In addition to databases holding information, telecommunications facilities are required to facilitate the sharing and use of data as well as to link businesses processes. Thus IT is central to inter-organisational cooperation as information is central to any sort of co-operation, and IT is valuable for manipulating information. By linking procedures within and between companies and enhancing the co-ordination and controlling function, information systems (IS) enable and enhance co-operation between companies in many ways.

From a technical perspective, telematics and telecommunication infrastructures, analogous to inter-organizational physical logistic systems termed information logistical infrastructures (Szyperski, Klein, 1993), are the basis for the efficient operation and cooperation of transactions and support the reorganisation and development of efficient and effective business relationships.

Inter-organisational systems (IOS) is a general term given to IT systems which enable the transfer of information across organisational boundaries. There are a number of specific IOS technologies, the best known and most prevalent is electronic data interchange (EDI), the Internet is another, well-known example. It is estimated that in 1995 over $50 \%$ of all business documents in the US are exchanged electronically. 


\section{ORIGINS OF IOS}

Rockart and Short (1989) suggest that IT's impact on organisations can be classified into five types. First, technology changes the organisation's internal structure (see, for example, the case of Gerling, an international insurance company, Loebbecke, Jelassi, 1997); second, it results in team-based, problemfocused work groups; third, inter-organisational systems are causing firms to become nebulous - that is they are shifting to a market rather than a hierarchical orientation by linking electronically or legally with suppliers, customers and potential competitors. Fourth, the technical perspective suggests that continuing improvements in computer and communications capabilities will lead to further systems integration within the business allowing organisations to think or act globally rather than locally if they wish. Last IT provides a new approach to managing interdependence.

Thus, organisations are being transformed from single location hierarchical structures with well-defined boundaries to more flexibly organised and dispersed configurations. The main drivers of this are information and communications technology, globalisation, customer service, a desire for risk and cost reductions and an increasingly competitive environment, all of which decompose organisations into smaller, focused units (see, for example, the case of the French bank CORTAL, the first fully IT-based bank in Europe, which has been successful since its foundtion in 1984, Loebbecke, Jelassi, 1994). Collaboration occurs on an inter-organisational basis as partnerships with suppliers and customers are increasingly important.

The co-ordination of activities by electronic markets and hierarchies has led to the emergence of electronic brokerage firms and electronic integration between organisations. Such markets reduce the costs and time required to acquire information. Bakos (1987) distinguishes between electronic information links and electronic markets. The former is a value added chain between two organisations while the latter have many buyers and sellers, usually with an intermediary. These intermediaries reduce search costs and can create critical mass.

These developments give rise to extended, or virtual, organisations where external boundaries are obscured by inter-organisational dependencies (e.g. the case of KHD, a German diesel engine manufacturer, see Loebbecke, 1996). The sharing of information, ideas and expertise becomes central to the success of such businesses. However, equally important is co-ordination and control. Decision making by geographically separated managers and teams is possible as concurrent access to data and communications using IT is available (Rockart, Short, 1989). However, difficulties of control and co-ordination mechanisms across organisational barriers have long been recognised as making transactions subject to substantial inefficiencies (Williamson 1975). Yet it is proposed that IT may improve coordination of these activities. 


\section{OVERVIEW: INTRA-INDUSTRY SYSTEMS AND CUSTOMER SUPPLIER SYSTEMS}

There is no doubt that systems that cross organisational boundaries offer the possibility of doing business in new ways through collaborating with competitors and working more closely with customers and suppliers. Celebrated cases such as American Airlines and American Hospital Supplies fuelled excitement in the 1980s about using IT to gain competitive advantage along the lines advocated by Porter (1980). These cases illustrate the two types of IOS that exist, intra-industry systems and customer/supplier systems.

An early example is how American Airlines gained advantage by the introduction and control of an airline reservation system (intra-industry systems), the rules of which could be set to favour American. As the first in the field (along with United), American was able to establish a presence in travel agents' offices, and competitors were faced with the option of participating in the established system or an uphill struggle to develop and introduce their own system. Many airlines chose the former and the seat reservation business became more profitable for American than running the airline. When the great shakeup occurred in the US after deregulation few airlines survived, but American and United did. United then attempted to use their reservation capability to redefine their business by extending into car and hotel reservation, though this was less successful.

In the case of American Hospital Supplies (AHS) the key was to get on-line terminals into the purchasing offices of hospitals. The simplicity and immediacy of the system (customer supplier systems) encouraged purchasers to buy from AHS, with AHS (now Baxter Healthcare) allowing its competitors as well as other producers access to their customers through the system. Increasingly it is the norm in particular industries for orders and invoices to be transmitted between customers and suppliers via EDI. There is the potential for much closer and broader links, including for instance, technical and logistical issues (e.g. Loebbecke, Jelassi, 1995). Engineering data can be shared between companies.

Retailers and manufacturers are also keen to improve responsiveness and reduce inventories through JIT delivery systems. Close cooperation is required between customer and supplier. JC Penny, the largest US retail department store chain, has tied in a number of apparel and fabric manufacturers, including JP Stevens, Milliken and Dupont, all giants in their own right. JC Penny automatically transmits orders to the fabric and fibre manufacturers, which then deliver the needed materials to the apparel manufacturers through a JIT delivery system. While each participant in the value-added information network benefits, the bulk of the benefits have accrued to JC Penny, whose profits reflect the wisdom of the investment (for a further example of a retail store chain, see Loebbecke, Kronen, Jelassi, 1996; Loebbecke, Kronen, 1994). 


\section{IOS PECULIARITIES (IOS VERSUS INTERNALLY-USED IS)}

Although technically IOS may not always differ from those systems that organisations use internally, there are a number of reasons why it is necessary for management to view them differently (Sprague and McNurlin, 1993; Cash et al, 1993):

- IOS require partners which implies a willingness and ability to interact.

- Standards play a key role, and these allow reuse of systems and hence economies of scale.

- Education is important and is often more of a hurdle than is the technology.

- 3rd parties are often involved who have roles in educating, developing or provide links.

- Work must be synchronised especially when systems and processes are upgraded.

- Work processes are often re-evaluated.

- Technical aspects are often not the major issue

- Efforts cannot be secretive - this might be taken to imply that competitive advantage from IOS is not sustainable.

- IOS introduce new and different challenges to the organisation's internal control, planning and resource allocation systems.

- Legal issues may arise in terms of replacement of physical entities such as orders by electronic exchanges.

- New roles for IOS facilitators as co-ordinators or providers of the IOS services may exist.

- IOS generally have a broader and more potential competitive impact than traditional internal uses of IT.

\section{MOTIVATIONS FOR AND RISKS OF IOS}

Beyond the possibility of doing business in new ways through collaborating with competitors and working more closely with customers and suppliers, and a suggested IOS-based movement from hierarchies (firms doing things themselves, internally) to markets (firms trading with others for a wider range of goods and services) with value-added partnerships, participants get the benefits of vertical integration and economies of scale, yet can remain small. Furthermore, the motivations for IOS include a desire to (Cash et al., 1993):

- reduce paper work and improve transaction efficiency,

- improve control of inventory or suppliers,

- strengthen channel control - that is, to improve distributor product awareness, or raise entry barriers. Though, virtually any IOS that works to strengthen a channel can also be designed to eventually bypass that channel,

- improve customer relationships,

- share resources or risks, 
- gain synergy from collaboration.

Of course, IOS are not without risks which must be set against these motivations, and which may be grouped as:

- technical - a lack of experience, the expense, the multitude of partners, and the geographical scope, organisations may join on efficiency grounds but actually find themselves with less bargaining power,

- legal and regulatory - most are not written with IOS in mind,

- organisational - the intended and unintended IOS impact on structure, control systems, and people.

To come to terms with the risks and to obtain the benefits organisations contemplating joining or establishing IOS need to (Neumann 1994):

- recognise the realities of the marketplace including

- the embedded information in products, structure etc, and the value of IT infrastructure

- the strategic necessity of leveraging information and IT that leverage requires co-operation,

- that IOS becoming infrastructure,

- recognise the realities of the firm:

- before entering an IOS understand the capabilities of the organisation,

- assess the values, commitment and capabilities of partners.

IOS-based alliances should be managed like separate companies and core operations should be changed to learn from alliances. In terms of managing IT, the IT infrastructure is a central asset in any IOS initiative, the development costs and risks are large and there is a need to decide whether activities are better performed less expensively or more flexibly by outside suppliers.

\section{IOS TYPOLOGY}

Reality shows a wide range of IS which are used jointly by companies which have joined forces. Depending on the functional scope ${ }^{1}$ and the IOS autonomy ${ }^{2}$,

1 What is the functional scope of the system? Is it the information backbone of a whole business, or is its use limited to specific functional segments? Does it support planning and/or operational activities? Does it focus on businesses the partners are already engaged in, or does it intend to develop new business opportunities?

What is the degree of autonomy of the IOS? IOS autonomy refers to the independence of the IOS of other IS implemented by the cooperating partners. If most functions of a CIS are distributed among the operational IS of the partners, IOS autonomy is low (e.g. EDI embedded in proprietary systems of the cooperating partners), while a IOS supporting a wide range of functions within a separate system possesses a higher degree of autonomy (e.g. carrier reservation systems). Generally, a high degree of IOS autonomy is observed in cooperations 
Loebbecke, Kronen (1996) suggest to distinguish three types of IOS on a horizontal level: (1) IOS that focus on the operation of inter-organisational activities, (2) IOS that stress the management of inter-organizational activities, and (3) IOS that trigger inter-organizational activities (see Figure 1).

\subsection{IOS Focusing on Operational Activities}

IOS that focus on the operation of inter-organisational activities are usually linked to other operation systems of the partners, they are characterized by a low to medium degree of autonomy. They support the operational business processes between cooperating partners, which can be linked only if information processes are also linked in a corresponding manner.

These systems occur in two different forms: They are either composed of several modules which belong to the proprietary operation systems of the cooperating partners, or they are a separate system which builds the integrating bridge between the partners' operation systems.

A range of purposes of IOS which focus on the operation of inter-organisational activities can be distinguished depending on the goals of a cooperation. Examples include order and delivery systems, production planning systems, or electronic sales support systems (see Table 1).

In a cooperation in the area of research and development, the partners' needs concentrate on the free flow of project-specific information. Systems which support groupwork, such as Lotus Notes, are readily available solutions to fulfill this objective. Procurement cooperations which aim at bundling buying volumes need features which support separate accounting and individual links to the partners' inventory systems. The fashion information planning system (FIPS) of a large European department store chain (see Loebbecke, Kronen, Jelassi, 1996) is a prominent example for such a system. Marketing cooperations, on the other hand, usually require IS for exchanging, retrieving and analyzing market information and customer data. The marketing cooperation of a gardening retailer and a book distributor is supported by IS: the gardening retailer forwards data on its customers with specific information about the products ordered to a book distributor who compiles and mails highly individualized offer lists with books of interest to the gardening retailer's clients. Management functions in cooperations, such as project management and controlling, still lack an IS support which fulfills cooperationspecific requirements.

which are business-idea driven. These settings are created to support a diversification strategy and therefore cannot be based upon existing IS. 


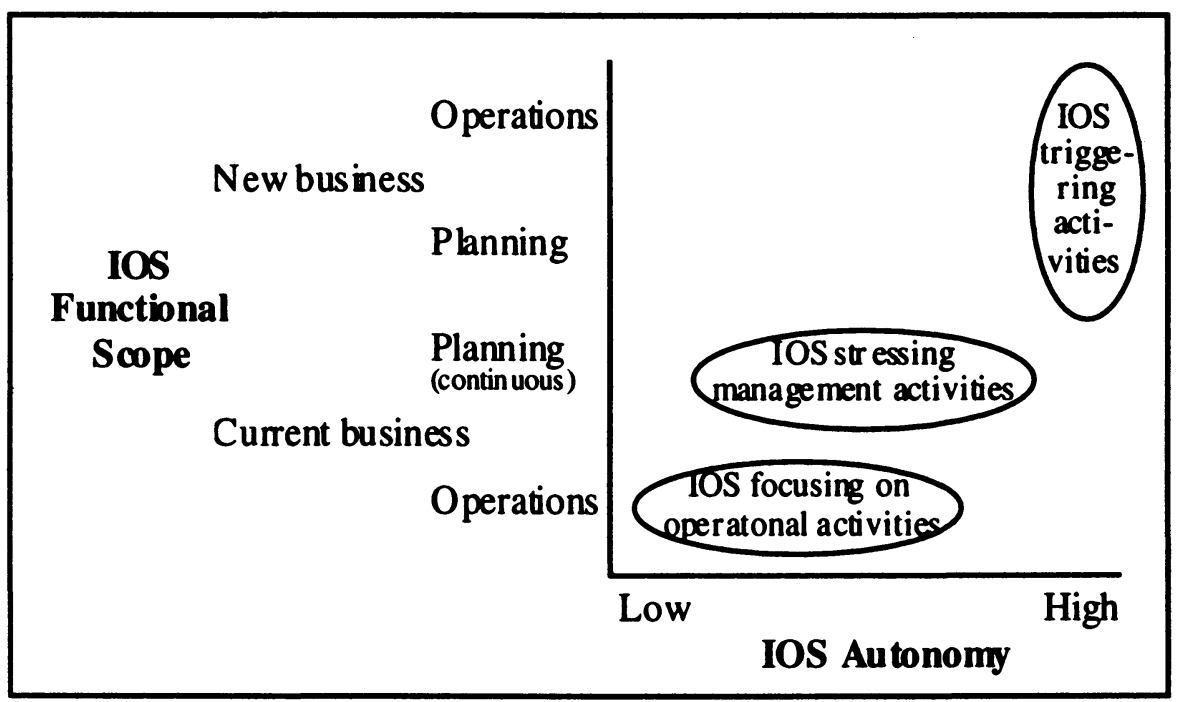

Figure 1 IOS Typology (after: Kronen, Loebbecke, 1996).

Practically speaking, cooperations are hardly restricted to only one of the functions mentioned in the table. In much cooperation, several functions of the value chain or separate systems are linked. For example, companies making joint bids or developing an interdependent range of products cooperate simultaneously in the areas of research, production and sales. The corresponding multiplication of interfaces between the partners' systems and the bi-directional, multiple data flow leads to sophisticated IOS requirements.

Further IOS requirements result from the structure of business processes: activities are often executed simultaneously in a decentralized manner. IOS therefore have to trigger and coordinate the sub-processes carried out by the partners as well as monitor the completeness of all activities.

Another well-known example of an IOS that focus on the operation of interorganisational activities are just-in-time systems among suppliers in the automotive industry. Due to the pyramidal structure of the supplier industry, the main contractor uses just-in-time systems to coordinate the delivery and assembly of modules. In such a context, competitive IOS constitute a valuable asset for the partners and contribute to survival of the supplier shake-out. ${ }^{3}$

A co-operation aiming at bundling functions or products from a customer's point of view is characterised by the interdependence of multiple functions. For instance, outsourcing, increasingly employed to manage a company's IT function, consists

3 The number of suppliers in the automotive industry generally decreases as the necessary relation-specific investments are increasing (for CAD/CAM systems, JIT systems). Bakos; Brynjolfsson (1993) emphasize the decreasing number of suppliers especially in a quality-oriented competition. 
of bundling functions specific to a company's needs. The outsourcer acts as an integrator and combines several services and products (hardware, system and application software, service, training), and thus reduces the company's transaction costs. Not only companies, but also consumers are developing a preference for 'one-stop shopping' instead of dealing with numerous providers (e.g., reservation systems for airline, hotel, and rental car; package tour; insurance broker).

Table 1 IOS focusing on the operation of inter-organisational activities

\begin{tabular}{|c|c|c|c|c|}
\hline $\begin{array}{c}\text { Area of Co- } \\
\text { operation/ } \\
\text { Operative } \\
\text { Function }\end{array}$ & $\begin{array}{c}\text { Available } \\
\text { Applications }\end{array}$ & $\begin{array}{l}\text { Co-operation- } \\
\text { specific } \\
\text { Requirements }\end{array}$ & & Examples \\
\hline $\begin{array}{l}\text { research and } \\
\text { development }\end{array}$ & $\begin{array}{ll}- & \text { e-mail } \\
\text { - } & \text { data bases } \\
\text { - } & \mathrm{CAD}\end{array}$ & $\begin{array}{ll}\text { unlimited } \\
\text { access to } \\
\text { project-specific } \\
\text { information }\end{array}$ & $\bullet$ & Lotus Notes \\
\hline procurement & $\begin{array}{ll}\text { - } & \text { procurement } \\
\text { systems } \\
\text { - } & \text { order entry } \\
\text { system }\end{array}$ & $\begin{array}{ll}\text { - } & \text { joint } \\
\text { - } & \text { procurement } \\
\text { separate } \\
\text { accounting } \\
\text { - } & \text { link to partner's } \\
\text { inventory } \\
\text { control }\end{array}$ & - & FIPS \\
\hline production & 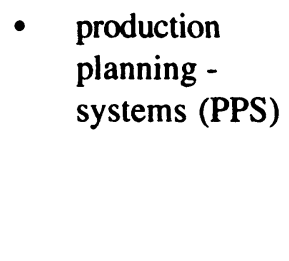 & $\begin{array}{ll}\text { - locally } \\
\text { distributed, } \\
\text { timely linked } \\
\text { production } \\
\text { - joint venture } \\
\text { production }\end{array}$ & - & $\begin{array}{l}\text { just-in-time } \\
\text { system among } \\
\text { suppliers of a } \\
\text { dashboard } \\
\text { system }\end{array}$ \\
\hline $\begin{array}{l}\text { sales and distri- } \\
\text { bution (pooling / } \\
\text { swapping sales } \\
\text { forces, products, } \\
\text { distribution } \\
\text { channels) }\end{array}$ & $\begin{array}{l}\text { - joint customer } \\
\text { data base } \\
\text { - joint } \\
\text { management of } \\
\text { sales force }\end{array}$ & $\begin{array}{l}\text { customer data } \\
\text { pools, } \\
\text { differentiated } \\
\text { along regions } \\
\text { and other } \\
\text { criteria } \\
\text { linked route } \\
\text { planning }\end{array}$ & - & $\begin{array}{l}\text { code sharing } \\
\text { among airlines } \\
\text { (e.g. Lufthansa } \\
\text { / United } \\
\text { Airlines co- } \\
\text { operation, } \\
\text { using Galileo }\end{array}$ \\
\hline
\end{tabular}




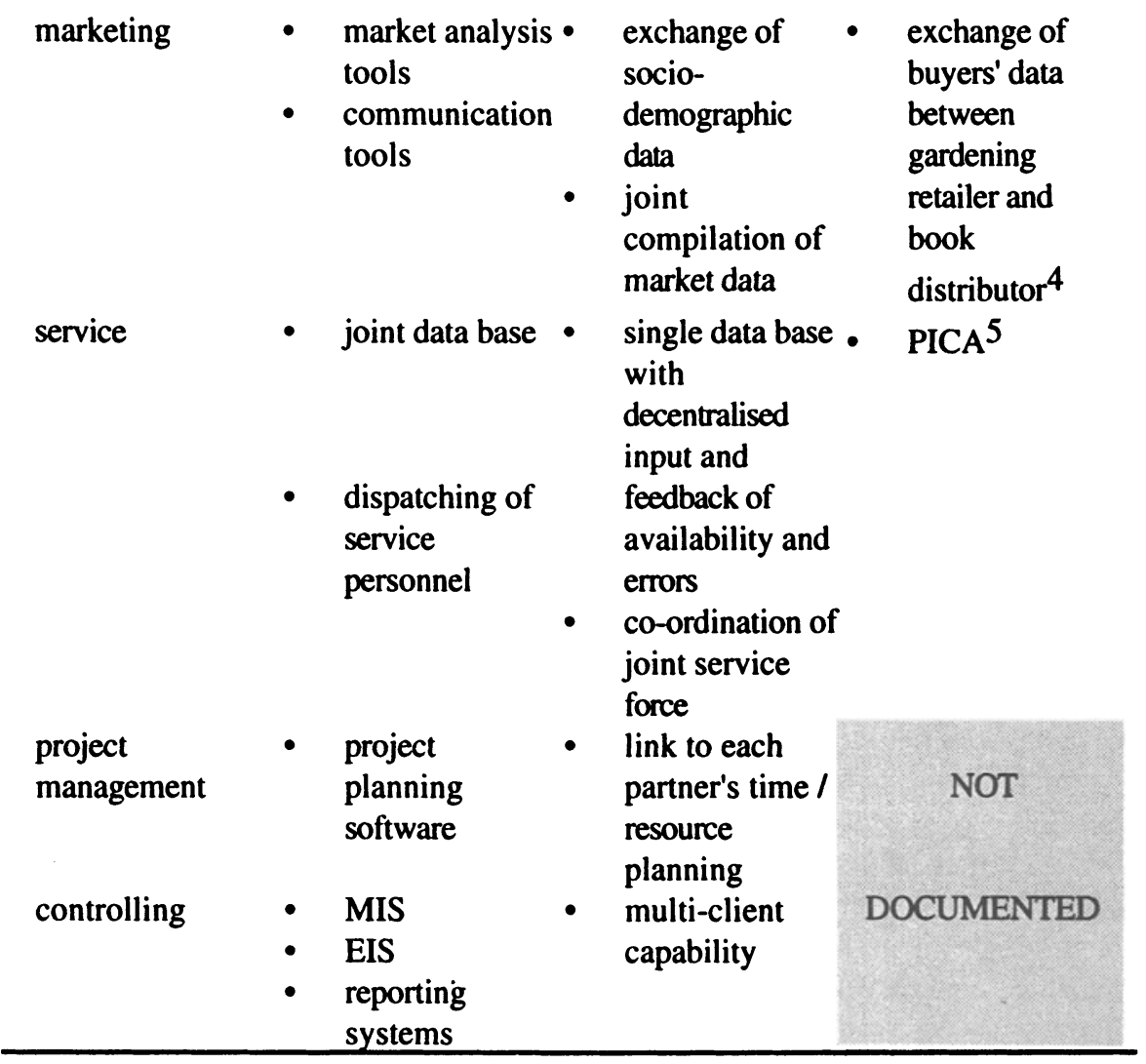

Source: Kronen, Loebbecke, 1996.

\subsection{IOS Stressing Management Activities}

Due to the low degree of integration with other applications, IOS stressing the mangement of inter-organizational activities posses a high degree of autonomy. They support mainly planning activities during the start-up phase as well as along the entire life-cycle of a cooperation.

The focus of activities in the phase of acquiring a cooperating partner and setting up the cooperation rests on strategic planning functions. IT provides numerous tools to support these tasks within a single enterprise. To manage a cooperation, already existing systems for internal strategic planning can be used. Examples

\footnotetext{
4 Cash, McFarlan, McKenney, 1992)

5 PICA (Project for Integrated Catalogue Automation) is an IOS of the Dutch public libraries to support the joint cataloguing and archiving activities (Wierda, 1991).
} 
include IS-based strength-weakness analyses, applications to segment strategic business units, and tools for project management or budget planning or control.

In order to be used in cooperation, these applications must fulfill cooperationspecific requirements. Therefore, their features have to be enlarged along three dimensions:

\section{(1) Contents}

Applications have to cover contents and details relevant to the cooperation/joint management activities. Models embedded in an application must allow for cooperative activities instead of only permitting competitive relations with other enterprises. An example is using an IT-supported competitor analysis for profiling and identifying potential cooperating partners. Electronic checklists, a convenient tool for strategic planning, must be enriched to contain cooperation-specific items for analyzing the company's needs for a cooperation or for selecting a cooperating partner.

\section{Multi-Client Capability}

All applications in cooperation must be able to treat the cooperative structure as a separate unit of analysis. The system has to be capable of recognizing the cooperation as a separate structure and the partner companies as the cooperation's 'clients', it must allow for several 'views' on the cooperation. In this context, data specific to the cooperation must be identified, manipulated and stored without being mingled with the partners' own business data.

Another requirement is to verify the compatibility between the cooperation's planning and project management data with each partner's figures and capacity restrictions. Shifting resources between partners gives each cooperation additional flexibility which should be fully exploited by a high-performing IOS.

\section{(3) Communication}

A final requirement of IOS that stress the mangement of inter-organizational activities is to permit links between the systems of all cooperating partners. In the case of informal communication, electronic mail provides a relatively stable and convenient tool based on wide-spread standards on the transportation layer of the OSI 7-layer model. A communication link on the application layer, however, is more difficult to implement, especially when striving for distributed applications, which require open system architectures.

Most applications for strategic planning provided on the market lack any form of integration. They are difficult to link with other applications, data cannot be imported from operations, etc. Cooperating partners, who want to use IS to support their cooperation management, have to make firm efforts to develop the required IOS features. 
Unfortunately, the IOS features discussed above are neither wide spread nor available on the market. Table 2 summarizes specific requirements for IOS that stress the mangement of inter-organizational activities.

Table 2 Requirements for IOS stressing the management of inter-organisational activities

\begin{tabular}{|c|c|c|}
\hline $\begin{array}{c}\text { Management } \\
\text { Function }\end{array}$ & $\begin{array}{c}\text { Available } \\
\text { Applications }\end{array}$ & $\begin{array}{c}\text { Co-operation-specific } \\
\text { Requirements }\end{array}$ \\
\hline strategic analysis & $\begin{array}{ll}\text { - } & \text { portfolio systems } \\
\text { - } & \text { value chain simulation } \\
\text { - } & \text { other simulation }\end{array}$ & $\begin{array}{l}\text { - } \\
\text { - } \\
\text { profiling potential co- } \\
\text { operating partners }\end{array}$ \\
\hline $\begin{array}{l}\text { planning and project } \\
\text { management }\end{array}$ & $\begin{array}{l}\text { project management } \\
\text { software } \\
\text { planning systems for } \\
\text { certain functions (e.g. } \\
\text { sales, budgeting, } \\
\text { procurement) } \\
\text { - electronic checklists }\end{array}$ & $\begin{array}{l}\text { - link with time / } \\
\text { resource management } \\
\text { of partners } \\
\text { co-operation-specific } \\
\text { items }\end{array}$ \\
\hline communication & $\begin{array}{ll}\text { - } & \text { groupware } \\
\text { - } & \text { e-mail }\end{array}$ & - inter-organisational \\
\hline controlling & $\begin{array}{ll}\text { - } & \text { MIS } \\
\text { - } & \text { EIS } \\
\text { - } & \text { reporting systems }\end{array}$ & $\begin{array}{l}\text { - } \quad \text { multi-client capability } \\
\text { joint control of co- } \\
\text { operation, including } \\
\text { feedback to partners }\end{array}$ \\
\hline
\end{tabular}

Source: Kronen, Loebbecke, 1996.

\subsection{IOS Triggering Inter-Organisational Activities}

IOS that trigger inter-organizational activities drive cooperation and are therefore their purpose and focus; they show a high degree of IS autonomy and usually cover a wide range of planning and operational functions. They are often the result of innovative business ideas and lay the ground for an IS-based diversification providing a new business opportunity unrelated to the sponsor's / participants' field of business.

Cooperation which aim at bundling functions, products or services are especially prone to use such systems. IOS that trigger inter-organizational activities facilitate to jointly offer the products of several suppliers and thus to offer convenience from a customer's point of view. American Airlines, Hilton hotels and Budget Rent-ACar have joined forces and IS resources in order to offer a full range of travel services to customers. The customer enjoys one-stop-shopping for all needs in air 
travel, accommodation and transportation. The reservation systems of all three partners have to be able to access a joint customer data base.

Cooperating partners in an information partnership draw conclusions from their joint data base which might lead to offering new products and services; thus such an IOS can be the starting point for highly differentiated services. For example, a carrier reservation system may be extended into specialized travel services for corporate clients. To fully exploit the strategic potentials of such an IOS, the continuous development and maintenance of information has to be a priority from the very beginning. At the same time, the cooperation's compatibility with the corporate strategy of each partner is crucial.

Most IOS that trigger inter-organizational activities are separate systems with clearly defined interfaces to the IS of the cooperating partners. In many cases, the operation of the IOS has been outsourced to the IS specialists of the system's sponsor, to a jointly funded company, or to an external service provider. Solving security problems in an adequate manner is a mandatory prerequisite for all of these arrangements.

Crucial for the success of such an IOS is the fast implementation of a new business idea while, due to the high degree of autonomy, technical integration with the partners' operation systems is not a top priority. Common procedures and standards are defined during the development phase of such an IOS, common codes for product and customer data have to be agreed upon. While an external service provider can make valuable contribution in this phase, the definition of functional requirements remains with the partners. Furthermore, the task to monitor and trigger the necessary adaptation of the IOS to the changing content of the cooperation must be fulfilled by the partners themselves.

\section{IOS IMPACTS}

Companies may cooperate for a number of reasons. In a cooperative arrangement, the balance between competitive and cooperative behavior is crucial for stability. The advantages of cooperating motivate the partners not to endanger the existence of the cooperation or its functionality by opportunistic behaviour. Two mair desired effects, which are discussed below, provide a strong incentive to cooperate and obey the rules. These desired effects also explain why cooperation built around an IOS that trigger inter-organizational activities regularly involve more than two cooperating partners: 
Table 3 IOS triggering inter-organisational activities

\begin{tabular}{|c|c|c|c|}
\hline $\begin{array}{l}\text { Strategic } \\
\text { Intent }\end{array}$ & $\begin{array}{c}\text { Available } \\
\text { Applications }\end{array}$ & $\begin{array}{l}\text { Co-operation- } \\
\text { specific } \\
\text { Requirements }\end{array}$ & Examples \\
\hline $\begin{array}{l}\text { procurement } \\
\text { pooling }\end{array}$ & $\begin{array}{l}\text { - order collection } \\
\text { system (with } \\
\text { invoicing } \\
\text { component) }\end{array}$ & $\begin{array}{ll}\text { - } & \begin{array}{l}\text { provider of } \\
\text { information } \\
\text { (price; freight }\end{array} \\
\text { space) } & \text { identifiable } \\
\text { - } & \text { commission } \\
\text { accounting } \\
\text { - } & \text { bulk orders } \\
\text { - } & \text { joint analysis of } \\
\text { suppliers' } \\
\text { behaviour } \\
\text { - joint quality } \\
\text { control }\end{array}$ & 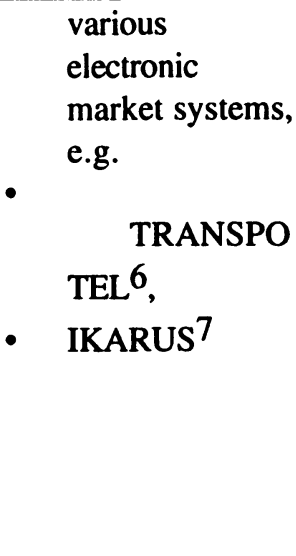 \\
\hline $\begin{array}{l}\text { bundling (Sales } \\
\text { / Distribution } \\
\text { Alliance) }\end{array}$ & $\begin{array}{ll}\text { - } & \text { carrier } \\
& \text { reservation } \\
& \text { systems }(\mathrm{CRS}, \\
& \text { e.g. SABRE) } \\
\text { - } & \text { information } \\
\text { partnerships }\end{array}$ & $\begin{array}{l}\text { joint customer } \\
\text { data base with } \\
\text { separate access }\end{array}$ & $\begin{array}{ll}- & \text { SABRE } \\
\text { - } & \text { American } \\
\text { Airlines / } \\
\text { Hilton and } \\
\text { Marriott Hotels } \\
\text { / Budget Rent- }\end{array}$ \\
\hline & & & $\begin{array}{l}\text { A-Car }{ }^{9} \\
\text { MAC (ATM } \\
\text { Network of } \\
\text { Philadelphia } \\
\text { National Bank) }\end{array}$ \\
\hline
\end{tabular}

6 TRANSPOTEL is a Swiss electronic market for available freight space (Hohagen, Schmid, 1991).

7 IKARUS is an EDI-based network for the allocation of freight space, sponsored by a consortium of the Irish air freight industry (Commission of the European Communities, 1992).

8 Hopper, 1990.

9 Cash, McFarlan, McKenney (1992). 


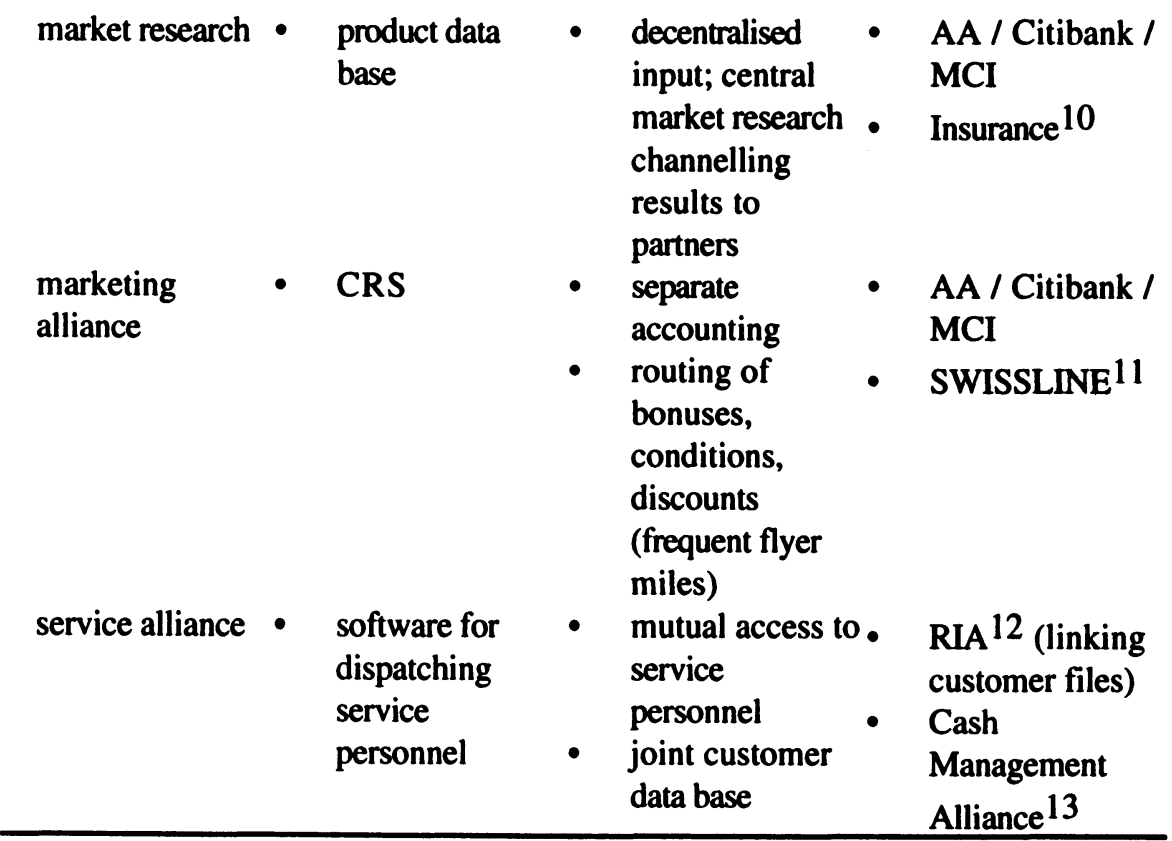

Source: Kronen, Loebbecke, 1996.

\section{(1) Virtual size and virtual diversity}

Cooperation based on IOS that trigger inter-organizational activities try to lever the bargaining power of the cooperating partners. A procurement cooperation can expect better conditions than a single member if the cooperation results in a higher procurement volume. A sales cooperation, offering a high volume or a wide range of products can lever its power over customers.

MUSIK (Commission of the European Communities, 1992) is an example of a sales cooperation of small suppliers in Europe, in which a new distribution channel is opened by cooperation. In MUSIK, small independent producers of

10 Porter; Millar (1985) discuss the example of an insurance company which extracts market research data from its contract data base to sell them as a separate product.

11 SWISSLINE is an accomodation reservation system, in which the Swiss Tourist Board, several regional Swiss tourist associations, and the Swiss Railroad cooperate (Ritz, 1991).

12 RIA's initiator Rosenbluth is an American travel service corporation for corporate travelling. All members of Rosenbluth International Alliance (RIA) have access to the sponsor's specific IS in order to provide world-wide customer service. RIA uses a widely-spread CRS as the carrier system for its proprietary system and thus utilizes the CRS geographic presence (Clemons, Row, Miller, 1992).

Cash; McFarlan; McKenney, 1992). 
classical music labels cooperate to produce and maintain an electronic catalogue which contains the products of all partners and it is updated directly. Orders and invoices are exchanged with wholesalers and retailers using the EDIFACT standard. The virtual range of products and the use of EDI reduce the transaction costs for music wholesalers and retailers to carry MUSIK products in their line. MUSIK increases the chances of carrying the stock, even if none of its individual members could succeed. At the same time, MUSIK acquires new customers who would not have dealt with individual members.

To jointly overcome market barriers to entry, IOS in service cooperation bundle the partners' service personnel to virtual service networks, guaranteeing geographical presence from a customer's point of view.

Furthermore, such IOS are often the 'backbone' in marketing cooperation. This cooperation type bundles complementary products and services to a functional unit from the customer's viewpoint. The customer can book a flight, reserve a hotel room and order a rental car by 'one-stop shopping'. In addition, marketing cooperation can increase customer loyalty for all partners by awarding the purchase of their products with low transaction costs or special discounts. From the suppliers' point of view (airline, hotel chain, car rental company), the IOS is a separate distribution channel.

The potential of marketing cooperation can be fully exploited only by building and using joint customer databases. The joint database accumulates during the life of cooperation and supplies valuable marketing data which could not be provided by external market researchers. Thus, the advantages of the cooperation reach far beyond increased customer loyalty and increased sales.

\section{(2) Scale effects}

Developing and operating an IOS that triggers inter-organizational activities usually causes high fixed cost, whereas the number of users only marginally affects operating cost. Therefore, the more partners use the system, the lower will be the cost for each partner, and the greater the spreading of the financial risks involved. The amortization of the IOS development cost - which is a sunk cost - is easier for a consortium, since the total is divided by all partners. However, the choice between founding a consortium and single sponsoring the IOS constitutes an entrepreneurial decision because the cost as well as the IOS-generated income have to be shared.

\subsection{Organisational Implications}

One fundamental consequence of IOS is that the cost of transactions between organisations is being reduced. The result is that there is less incentive to integrate businesses vertically or horizontally, businesses can operate on a smaller scale and extended, networked organisation become possible. A further consequence is that organisation and geography become separable. Businesses are no longer defined by 
their geography. Cash et al. (1993) suggest that the winners in using IOS will be small, flexible organisations that take advantage of IT-driven integration and synergy. Economies of scale-may no longer be sufficient to offset the disadvantages of size and complexity.

At a general level IOS will enhance flexibility in terms of productivity and competitiveness (Cash, Konsynski, 1985). Specifically, IOS may increase and decrease an organization's flexibility in a number of ways (Golden, Powell, 1995).

Organisational implications resulting from IOS may include that the entire organisational units may be disbanded while others are created; and that new management challenges of control, the flow of information and knowledge, legal, intermediaries, strategic participation, etc arise (Neumann, 1994). Changes will have to take place in procedures, style, culture, structure and strategy and the extent of these changes may depend on the reactive or proactive stance of management. If these implications turn out to be true, then managers must prepare for a fundamental shift in the way that they do business.

\subsection{Altered Business Relationships}

IOS enable electronic integration of the elements of a value chain. This provides possibilities for shortcutting by eliminating some stages such as distribution. Fewer stages should result in a more flexible value chain given that response time should be reduced. A second form of restructuring takes place as a result of organisations creating closer links with a reduced number of trading partners. Moves to fewer preferred suppliers creates longer-term, co-operative relationships, which enable the entire value chain to be more flexible.

\subsection{Restructuring of Organisational Boundaries}

Organisational boundaries are restructured by IOS because of the increased capability for co-ordination-intensive business structures which they provide (Davenport, Short, 1990). This may lead to a return, in certain industries, to small family networked organisations as in the pre-Industrial Revolution (Malone, Rockart, 1992). This may, in turn, lead to an increase in outsourcing and the creation of flexible business networks, to which trading partners can be added and subtracted easily (Venkatraman, Zaheer, 1994). Thus vertical integration becomes possible without the disadvantage of inflexibility due to ownership.

\subsection{Electronic Delivery of Business Documents}

Given that $70 \%$ of business data that is manually entered into a computer is the output from another computer, delivering business documents through IOS results in a reduction in the time taken between ordering and dispatch of goods, and may enable organisations to introduce just in time purchasing. This increases flexibility to adapt to market demands since a reduced amount of inventory is held in the 
complete value chain. The electronic delivery of business documents may also increase flexibility due to the increased availability of information leading to better decision making.

\subsection{Increased Dependence on Information Technology}

Conversely, the adoption of IOS may lead to a decrease in flexibility. By introducing IOS an initiator organisation becomes more dependent on technology. Increased use of IT may reduce flexibility because of the inability of information systems to change.

\subsection{IOS Messaging Standards}

In order to exchange business documents electronically specific messaging standards are needed. The variety of standards has been blamed for the slow development and application of EDI (Edwards, 1987). Standards are set by bodies whose main aim is to design message standards which possess a great deal of flexibility to ensure that the needs of different organisations can be expressed. But in order to achieve flexibility, standards have become too all inclusive. This increases the investment required by each set of trading partners to enable electronic understanding and may inhibit or at least delay in EDI diffusion. A way of reducing the investment is to introduce a sub-set of standards, but this eliminates the flexibility of an open, universal standard (Horluck, 1994).

\subsection{Non Inter-operability of Communications Networks}

Organisations who conduct EDI using an accepted non-proprietary standard normally communicate using an independent value added network (VAN) which provides the telecommunications facilities which enable the partners to exchange messages. VANs enable flexibility at the level of the network because they provide facilities which enable trading partners to be added or deleted. Yet, the inability to exchange messages between VANs restricts an organisation's trading partners to those using a particular VAN and thus reduces flexibility.

Participants in a value chain may differ in the extent to which each benefits by the introduction of IOS. Flexibility derived from EDI adoption is dependent on the size of the organisation, the IT expertise of the organisation and whether the organisation is the initiator of the project (Swatman et al., 1994).

\subsection{Shift towards Markets Structures}

IOS can enable low transaction costs, provide communications capabilities that overcome geography and provide easy access to information which reduces the cost of search. These are the ingredients required to allow creation of electronic markets 
which can offer convenience, speed and automated administration to handle volumes of business that could not be contemplated with manual systems.

Some markets, such as stock and commodity markets, are natural candidates for electronic systems. Less obviously the capability of IT to support electronic marketplaces translates into economic forces which encourage single source sales channels to evolve into electronic markets (Malone et al, 1989). Often a dominant player is well positioned to create an electronic market, but if no single player is sufficiently powerful, an industry association may be the initiator.

\section{IOS PLANNING AND DESIGN}

Existing IS reflect organizational structures which are often outdated. In order to support cooperations, the functional scope of existing IS has to be extended. Especially flexible and project-oriented forms of the division of labor between companies were not taken into account when the present IOS generation was designed. Communication audits, often the empirical base for IS design, do not routinely examine communication flows across the border of the organization. While numerous developments on the technical level support working in distributed architectures, current enterprise models do not emphasize these recent developments and therefore show deficits in designing flexible boundaries of the firm.

IOS often evolve in an organisation from automating paper-based transactions to process integration between the partners. Such an evolution requires that processes be altered to take account of the potential of IT, which involves altering working practices and responsibilities among network participants. IOS designers need to recognise that these systems affect organisations at many levels, and that linkages must go beyond electronic data interconnection to deal with people, policies and procedures (Konsynski, 1992). IOS tend to be implemented on an ad hoc basis, hindered by an absence of appropriate planning. This is not surprising given that many IOS tend to start operational (eg EDI) and become strategic. The lack of planning is the result of inadequate experience of multi-organisational planning environments and poor methodological guidelines.

Though IOS affect organisational structure, strategy, style, systems, skills and staff, the order that these effects occurs in depends on strategic intent and the planning involved in the systems introduction. If an organisation participates in an IOS agreement in an ad hoc manner, there is generally no broad management participation and no explicit planning or consideration given to the implications of participation. Hence, the initial effect that participation has is on systems such as procedural reports and routine processes. Also the skills or distinctive capabilities of key personnel or perhaps of the entire organisation will change. Finally, there will be effects in relation to organisational style, structure and strategy as managers alter the organisation's goals and how these are achieved as a result of IOS participation (Cash, 1985). 
Typically IS planning has focused exclusively on the internal functions of the business. This conventional view targets information systems applications at an organisation's planning and control processes. While such perspectives have served well in the past, a different type of IS planning method is required for IOS. Such methods should have foundations in competitive strategy rather than in planning and control.

IOS planning has distinct characteristics that differentiates it from internal IS planning. Essentially, IOS planning can be undertaken by adopting planning approaches for telecommunications, EDI, groupware, and business process redesign. However IOS deal with a large number of people, policies and procedures and, therefore, require more extensive planning than internal IS planning or planning for individual technologies. In addition no integrated methodology exists which guides planning for IOS in their entirety. This is in contrast to intraorganisational IS planning.

For example, EDI is a complicated technology and many organisations do not recognise it is a business issue that requires more than just "hooking a couple of computers together and starting to send data" (West, 1994); the successful implementation of groupware requires more than installing the software as multiple participant involvement and organisational considerations are paramount (Bullen, Bennet, 1990). However, planning guidelines for group technology are more limited that those for EDI. Most guidelines emphasise an iterative approach, relying more on pilot projects than on planned introductions. However, certain aspects such as the support of top management and the alignment of the technology with organisational objectives are recognised as important (Opper, 1994). Nevertheless, while such planning guidelines are largely inadequate on an individual organisational basis, they are impossible when multiple independent organisations, with often conflicting objectives, are involved, as in IOS.

Although IOS designers often minimise changes to business processes in an attempt to minimise resistance to the new system, some form of structural integration involving the redesign of business processes is required to fully benefit from inter-organisational cooperation (Benjamin et al, 1990). In fact, BPR efforts that focus on the market network are potentially more important than their internal counterparts (Short and Venkatraman, 1992). Particularly on an inter-organisational basis, multiple participant organisations with disparate objectives need more precise plans before moving towards process redesign and structural integration.

In the future, IOS design has to take into account new models of intercorporate links in order to support the emerging number and variety of cooperations. Corporations cannot afford to let the opportunities pass which can be exploited by joining forces, just because their information systems lack capabilities of IOS or even do not allow links to any form of IOS.

The value of IOS-based cooperations stems partially from their potential for restructuring and rationalizing internal structures and processes, known as BPR. Designing IOS and organizational structures is a highly mutual adaptation process. 
On the one hand, IOS should be customized to specific needs of an organization, on the other hand, they should not be adapted to existing structures without questioning them thoroughly.

\section{SUMMARY AND CONCLUSION}

Inter-organisational systems (IOS) have received much attention recently by both business and researchers. This is not to say that organisations have not had links with others over the last few centuries, nor that firms have not operated globally for decades. Rather, it is technological developments in communications and networking and management moves such as outsourcing, partnerships and just-intime production which have given a new capability and impetus to these issues.

This chapter discussed inter-organisational systems and identified why managers need to consider them differently from other, internal information systems (IS). It looked at different types of IOS along the dimensions of functional scope and IOSautonomy, IOS-induced business transformation, and issues of IOS planning and design. Furthermore, this chapter outlined new business opportunities by combining the mutually interdependent strategy of cooperation and IOS which span corporate boundaries. It therefore intended to encourage practitioners to identify the chances provided by the cautious development of IOS and by conceptualizing new businesses which are fully leveraged by the creative use of IOS.

\section{REFERENCES}

Bakos, J. Y. (1987) Inter-organisational Information Systems: Strategic Opportunities for Competition and Co-operation. Ph.D. Dissertation, MIT Sloan School of Management.

Bakos, J. Y., Brynjolfsson, E. (1993) Why Information Technology Hasn't Increased the Optimal Number of Suppliers, in Information Systems: Collaboration Technology, Organisational Systems and Technology, (eds. Jay F. Nunamaker; Ralph H. Sprague) Proceedings of the Hawaii International Conference on System Sciences 26, Vol. IV, 799-808.

Benjamin, R., DeLong, D., Scott Morton, M. S. (1990) Electronic data interchange: How much competitive advantage?. Long Range Planning, 23 29-40.

Bullen, C.V., Bennett, J. L. (1990) Learning from user experience with groupware, Proceedings of the Conference on Computer-Supported Co-operative Work, 291-302.

Cash, J. I. (1985) Inter organisational systems: An information society opportunity or threat?. The Information Society, 3, 199-228.

Cash, J. I., Konsynski, B. R. (1985) IS redraws competitive boundaries. Hanaand Business Review, 2, 134-142. 
Cash, J., McFarlan, W.F., McKenney, J. L. (1992) Corporate Information Systems Management: The Issues Facing Senior Executives, 3rd ed., University of Illinois Press, Homewood, III.

Cash J., Eccles R., Nohria N., Nolan R. (1993) Building the Information-Age Organisation, Irwin, New York.

Clemons, E. K., Row, M. C., Miller, D. B. (1992) Rosenbluth International Alliance: Information Technology and the Global Virtual Corporation, in Information Systems: Collaboration Technology, Organisational Systems and Technology (ed. Jay F. Nunamaker; Ralph H. Sprague), Proceedings of the Hawaii International Conference on System Sciences 25, Vol. IV, 678-688.

Commission of the European Communities (1992) TEDIS - Technical, Organisational and Managerial Aspects of Implementing EDI - Results and Experiences of 12 EDI Pilot Projects, Brussels.

Davenport, T. H, Short, J. E. (1990) The New Industrial Engineering: Information Technology and Business Process Redesign, Sloan Management Review.

Edwards D. W. (1987) Electronic Data Interchange: A Senior Management Overview, ICIT Briefing Paper.

Golden W., Powell, P. (1995) The Effects of Inter-Organisational Information Systems on Flexibility, Working Paper.

Hohagen, U., Schmid, M. (1991) Stand und Entwicklungstendenzen Elektronischer Märkte in der Logistik, Working Paper No. IM2000/CCEM/7 of the 'Institut für Wirtschaftsinformatik', Hochschule St. Gallen, Switzerland.

Hopper, M. D. (1990) Rattling Sabre - New Ways to Compete on Information. Harvard Business Review, May-June, 118-125.

Horluck J. (1994) The Pragmatics of Electronic Data Interchange: The Use of EDI will Unify Business Procedures. International Journal of Information Management, 14, 330-343.

Konsynski, B. R. (1992) Issues in design of inter-organisational systems, in Challenges and Strategies for Research in Systems Development (eds. Cotterman, W. W., Senn, J. A.) Wiley, Chichester, England.

Kronen, J., Loebbecke, C. (1996) Co-operation Information Systems (CIS) Typology and Illustrative Examples, EDI-IOS (Electronic Data Interchange Inter organisational Systems) Conference, Bled, Slovenia.

Loebbecke, C. (1996) Innovative IT-based Logistics - KHD's 'Vision 2000' engine factory, EDI-IOS (Electronic Data Interchange - Inter organisational Systems) Conference, Bled, Slovenia.

Loebbecke, C., Jelassi, T. (1994) Home Banking: An I. T. Based Business Philosophy or a Complementary Distribution Channel CORTAL versus Crédit Comercial de France', in: Strategic Management of Information Technology: Some European Case Studies (ed. T. Jelassi), Prentice Hall, New York - London - Toronto - Sydney - Tokyo - Singapore. 
Loebbecke, C.; Kronen, J. (1994) FIPS - An Innovative IT Application for Fashion Purchase in a European Department Store. Association of Management Conference Proceedings, Dallas, USA.

Loebbecke, C., Jelassi, T. (1995) Business Process Redesign at CompuNet Standardising Top Quality Service Through Information Technology. Joumal of Strategic Information Systems (forthcoming).

Loebbecke, C., Kronen, J., Jelassi, T. (1996) The Role of IT in Retailing: The Case of Supporting Fashion Purchasing at a European Department Store Chain. Journal of Strategic Information Systems, 5, 67 - 78.

Loebbecke C. and Powell P., (1997) Inter-organisational Systems: Scope, Impact and Competitiveness, in Inter-organisational Systems (ed. S. Strzelczak ),

Loebbecke, C., Jelassi, T. (1997) Concepts and Technologies for Virtual Organising: the Gerling Journey. European Management Journal, 15, 138146.

Malone, T. W., Yates, J., Benjamin, R. I. (1987) Electronic Markets and Electronic Hierarchies. Communications of the ACM, 30, 484-497.

Malone, T. W., Rockart J. F. (1992) Information Technology and the New Organization. Proceedings of the Hawaii International Conference on System Sciences IV, 636-643.

Neumann, S. (1994) Strategic Information Systems, Macmillan, New York.

Opper, S. (1994) Choosing and implementing a groupware system, Datapro.

Porter, M. E. (1980) Competitive Strategy: Techniques for Analysing Industries and Competitors, Free Press, New York.

Porter, M. E., Millar, V. E. (1985) How Information gives you competitive Advantage. Harvard Business Review, July-August, 149-160.

Ritz, D. (1991) Aktuelle Entwicklungen bei touristischen Informations- und Reservierungssystemen, Working Paper No. IM2000/CCEM/9, Institut für Wirtschaftsinformatik, Hochschule St. Gallen, Switzerland.

Rockart, J. R., Short, J. E. (1989) Information Technology in the 1990s: Managing Organisational Interdependence. Sloan Management Review, Winter, 7-17.

Short, J. E., Venkatraman, N. (1992) Beyond business process redesign: Refining Baxter's business network. Sloan Management Review, Fall, 7-21.

Sprague, R., McNurlin B, (1993) Information Systems Management in Practice, Prentice-Hall International, Englewood Cliffs.

Starkey, K., Wright, M., Thompson, S. (1991) Flexibility, Hierarchy, Markets. British Journal of Management, 2, 165-176.

Stoneman, P. (1986) Technological Diffusion: The Viewpoint of Economic Theory. Ricerche Economiche, XL, 4, 585-606.

Swatman, P. M. C., Swatman, P.A., Fowler, D. C. (1994) A model of EDI integration and strategic business reengineering. Journal of Strategic Information Systems, 3, 141-160. 
Szyperski, N., Klein, S. (1993) Informationslogistik und virtuelle Organisation Die Wechselwirkung von Informationslogistik und Netzwerkmodellen der Unternehmung. $D B W, 53,187-209$.

Venkatraman, N (1991) IT Induced Business Reconfiguration, in The Corporation of the 1990s: Information Technology and Organisational Transformation (ed. M. S. Scott Morton), Oxford University Press, Oxford.

Venkatraman N., Zaheer A. (1994) Electronic Integration and Strategic Advantage: A Quasi-Experimental Study in the Insurance Industry, in Information Technology and the Corporation of the 1990's (eds. Allen, M. S. Scott Morton), Oxford University Press, 184-201.

West, L. J. (1994) Breaking down the barriers to EDI implementation. TMA Journal, 14,10-15.

Williamson, O. (1975) Markets and Hierarchies, Free Press, New York.

Wierda, F. W. (1991) Developing Inter organisational Information Systems, Dissertation at the University of Delft, Netherlands.

\section{BIOGRAPHIES}

Claudia Loebbecke received a Master in Business and a $\mathrm{PhD}$ from the University of Cologne, Germany, and an M.B.A. from Indiana University. She worked as Consultant with McKinsey \& Co. in Germany, as Research Assistant at INSEAD in Fontainebleau, France, as Research Consultant at the Hong Kong University of Science and Technology (HKUST), and as Visiting Professorial Fellow at the University of New South Wales, Sydney. She regularly presents at international IS conferences, teaches master sutdents and executives in Cologne and abroad, and participates in several national and international research and consulting projects.

Philip Powell received his PhD from Southampton University. He is Director of the Information Systems Research Unit, Warwick Business School and an ICAEW Academic Fellow. He has authored books on information systems and financial modelling, and has published in Omega, JORSBritish Journal of Management, Organizational Computing, Journal of Strategic Information Systems, Journal of Management Systems, and Decision Support Systems amongst others. $\mathrm{He}$ is Managing Editor of the Information Systems Journal.

Pat Finnegan is a lecturer in Information Systems at University College Cork, Ireland, and a senior researcher with the Executive Systems Research Centre (ESRC). His research interests include IS Planning, Inter-Organisational Systems, Electronic Commerce and Information Systems for multinationals. He is completing a PhD at Warwick Business School.

William Golden is lecturer in the Department of Accountancy and Finance at University College Galway, Ireland. His research interests include InterOrganisational Systems, Electronic Commerce and issues of flexibility. He is completing a PhD at Warwick Business School. 